\title{
Improving the Scientific Integrity of Nontechnical Publications
}

\author{
By Jeremy D. Maestas, John Hughes, Theodore P. Toombs, Kirk W. Davies, Michael A. Gregg, \\ Carolyn Johnson-Nistler, Wendell C. Gilgert, and Steven L. Petersen
}

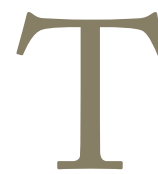

he June 2006 edition of Rangelands provides an opportunity for us to highlight a couple of points about the role of peer review in nontechnical publications produced by the SRM. This wildlife-themed issue was thought-provoking, informative, and for the most part accurate in its portrayal of some wildlife conservation issues facing resource managers. However, the articles by Schroeder et $\mathrm{al}^{1}$ and Brunner ${ }^{2}$ regarding sagegrouse help illuminate 2 points about SRM's nontechnical publications: 1) the need for a rigorous peer-review process in publishing issue papers, and 2) the need to clearly separate peer-reviewed literature from editorial pieces in Rangelands.

In the Viewpoint article by Schroeder et $\mathrm{al}^{1}$, the authors provide a detailed critique of the SRM Issue Paper titled "Ecology and Management of Sage-Grouse and SageGrouse Habitat." ${ }^{3}$ Their assessment revealed many legitimate problems with the information presented in the issue paper, such as the lack of references for stated facts and unsupported interpretations of existing data. These problems stemmed largely from the issue paper review and publication process. To our knowledge, the issue paper did not undergo formal and rigorous peer review by experts in the field of sage-grouse and sage-grouse habitat. SRM's Wildlife Habitat Committee (WHC) was informally given the opportunity to provide information on sage-grouse, but surprisingly was not intimately involved in developing or approving the issue paper.

At the 2006 SRM annual meeting in Vancouver, the WHC discussed the fundamental problems with the issue paper publication process. As a committee, we made a request to the SRM Board of Directors to develop a formal process for the publication of issue papers that includes peer review. We commend the Board for quickly adopting guidelines for the development of issue papers that should improve the rigor of these nontechnical publications. The issue $\mathrm{pa}^{-}$ per guidelines are now posted on the SRM website at: www. rangelands.org/publications_issuepapers.shtml.
Disseminating nontechnical information on species of concern, such as sage-grouse, is highly important and valuable if done in a scientifically sound manner. However, as Schroeder et $\mathrm{al}^{1}$ point out, we have a responsibility as scientists to present material based upon the best-available and most current research, which includes peer-reviewed literature from inside and outside SRM. The SRM Sage-grouse Issue Paper $^{3}$ serves as a good example of why we need to use a rigorous peer-review process for widely distributed nontechnical publications that represent SRM as a scientific society.

Our second point regarding peer review in nontechnical publications can be made by critiquing the article by Brunner $^{2}$ titled "Sage-Grouse at the Crossroads" that appeared in Rangelands. This article was not identified as having been peer reviewed, but it did appear in the "Feature Articles" section alongside peer-reviewed papers. Unfortunately, much of the information presented by Brunner ${ }^{2}$ on sage-grouse biology, habitat requirements, and relationships to domestic livestock grazing is not supported by scientific research. It is impossible, though, for individuals unfamiliar with sage-grouse biology and management to know whether the assertions are based on science, anecdote, or opinion because statements of fact are made with no literature citations.

Brunner $^{2}$ also provides inaccurate information on the potential effect of the Endangered Species Act (ESA) on private landowners. The article states that "A landowner simply cannot afford to have an endangered or threatened species on his land. He faces $\$ 75,000$ fines plus jail time if a bird is 'harassed', ie, flushed as the person drives over his own land." This statement is false; criminal penalties under Section 11 of the $\mathrm{ESA}^{4}$ can only be imposed for those who "knowingly violate" its prohibitions, which can include harassment. These statements are concerning given that many of us in SRM work with farmers and ranchers every day to improve habitat for species of concern while keeping the goal of agricultural production at the forefront. Endangered species conservation 
can occur without threatening private property rights, as evidenced by the article on the Malpai Borderlands Group by Allen ${ }^{5}$ in the same issue of Rangelands. Erroneous statements like that made by Brunner ${ }^{2}$ can lead to exaggerated misperceptions of the ESA by those unfamiliar with it, encourage further polarization amongst groups and private landowners, and potentially undermine the efforts of resource managers working to conserve threatened and endangered species on private land.

It is our view that articles of this nature be considered editorials and not be interspersed among peer-reviewed literature in Rangelands. Even though Rangelands does identify peer-reviewed papers as such in the fine print, we believe more needs to be done to separate them from editorials. One of the dangers in mixing these 2 types of articles is that it can confuse the reader about whether or not information is factual and based in science. This is particularly troublesome given the unique audience of Rangelands. SRM is fortunate as a scientific society to have nonscientists, such as farmers and ranchers, who actively participate in the Society and read our publications. We believe many nonscientists view SRM's nontechnical publications as a reliable source of sound information on rangeland management. For that reason, we have a responsibility to ensure the accuracy of statements and facts published in our professional literature.

We are not advocating that opinions be suppressed within SRM's publications. In fact, we agree with the view of SRM President John Tanaka ${ }^{6}$ that our Society should be a "Safe Haven" for debating all rangeland management issues and viewpoints. However, we recommend all editorials published in Rangelands be consistently placed in a distinct department, such as "Viewpoint" or "Letters to the Editor." We also suggest a disclaimer be added to the beginning of editorials that acknowledges the article reflects solely the views of the author(s) and that it has not been peer-reviewed for accuracy by Rangelands. Finally, we recommend all articles published in the "Feature Articles" department be peer-reviewed. These suggestions are consistent with the stated objective of Rangelands on the SRM website "to provide scientifically correct information."

Nontechnical publications produced by SRM are invaluable for explaining complex information about our rangeland resources, stimulating thoughts and discussions, and demonstrating how we are a relevant and pragmatic Society. We support and encourage the publication of issue papers and nontechnical articles in Rangelands. Yet we believe that scientific integrity needs to be preserved in all our professional publications, and we hope that our comments are constructive to that end.

Authors are Wildlife Biologist, USDA-NRCS, $1030 \mathrm{~W} 5370$ S, Murray, UT 84123, jeremy.maestas@ut.usda.gov (Maestas); Fish E̋ Wildlife Biologist, USFWS, PO Box 713, Canadian, TX 79014, jobn_P_hughes@fws.gov (Hughes); Ecologist/Policy Analyst, Environmental Defense, 2334 N Broadway, Boulder, CO 80304,ttoombs@environmentaldefense.org (Toombs); Research Rangeland Management Specialist, USDA-ARS, 67826A Hwy 205, Burns, OR 97720, kirk.davies@oregonstate.edu (Davies); Land Management E Research Demonstration Biologist, USFWS, 3250 Port of Benton Blvd, Richland, WA 99354, mike_gregg@fws.gov (Gregg); Associate Extension Wildlife Specialist, Montana State University, 101 Linfield Hall, Bozeman, MT 59717-2900,nistler@montana.edu (Johnson-Nistler); Wildlife Biologist, USDA-NRCS, 1201 NE Lloyd Blvd, Suite 1000, Portland, OR 97232, wendell.gilgert@por.usda.gov (Gilgert); Assistant Professor, Department of Rangeland Ecology EO Management, Oregon State University, 202 Strang Ag Hall, Corvallis, OR 97331, steven.l.petersen@oregonstate.edu (Petersen). Authors are members of the SRM Wildlife Habitat Committee. Views expressed in this article may not reflect those of other committee members or our employers.

\section{References}

1. Schroeder, M. A., J. W. Connelly, C. L. Wambolt, C. E. Braun, C. A. Hagen, And M. R. Frisina. 2006. Society for Range Management Issue Paper: Ecology and management of sage-grouse and sage-grouse habitat - A reply. Rangelands 28(3):3-7.

2. Brunner, J. 2006. Sage-grouse at the crossroads. Rangelands 28(3):15-16.

3. Society For Range Management. 2005. Ecology and management of sage-grouse and sage-grouse habitat: Issue paper created by the Society for Range Management. Wheat Ridge, CO: Society for Range Management.

4. Endangered Species Act Of 1973 (ESA). Section (11)(b)(1). 30 July 2006. http://www.fws.gov/Endangered/esaall.pdf

5. Allen, L. S. 2006. Collaboration in the borderlands: The Malpai Borderlands Group. Rangelands 28(3):17-21.

6. TANAKa, J. 2006. Are we a safe haven for science? SRM Member Resource Nerws. June Issue. p. 3-4. 